\title{
Models for Arts and Culture Financial Support*
}

\author{
Tatiana Abankina \\ National Research University Higher School of Economics, Moscow, Russia
}

\begin{abstract}
The purpose of this paper is to identify main approaches for the state support of cultural sector, their underpinning concepts and complex of financial instruments, using Russian and international practice. The paper examines and builds connections among basic theories, objectives, and financial instruments shaping main approaches to the public support of cultural sector and compares three corresponding models - paternalistic, investment, and stimulating. Three different models of public support for arts and culture: Paternalistic model implies making compensation of the objective revenue deficit in the cultural institutions with the aid of budgetary allocations; investment model means increasing government investment in the humanitarian field to ensure the transition to the innovation and knowledge-based economy and to sustainable social and economic growth; stimulating model implies creating conditions for the cultural industries development and creative class attraction, providing international competitiveness of the nations and cities in the global economy. The paper concludes that the models are not necessarily alternative, they complement each other rather than exclude. The paper, exploring the evolution of government support models for arts and culture, contributes to the discussion on the approaches to public financing for cultural sector in times of the budgetary restrictions on public spending and the changed role of culture in the society.
\end{abstract}

Keywords: financing arts and culture, patronized goods, human capital, creative economy

Recent decades, throughout the world, including Russia, saw apparently changing understanding of the role culture plays in society; structure of cultural economics in the modern world, and economic mechanisms and management technologies are to provide necessary inflow of resources to cultural sector. For a long time, culture was considered to be a costly sector, from the economic point of view. A dominating concept was that of an "inherent value" of culture-It should be supported as a certain aggregate of the accumulated public wealth, cultural heritage, and artistic achievement, valuable as it is. Financial basis for the cultural organizations' operations was formed mainly at the expense of budget funding or sustained financial support from other establishments - patrons. Cultural organizations were dealing with the "high" and "eternal", engaged in preserving culture "for generations to come" and giving more and more people access to the arts. Which of the arts they were giving access to seemed less important compared with the very idea of the Enlightenment. Traditionally, the management of cultural organizations is regarded distinctly different of that of business organizations, therefore the important thing is to protect the high culture from the tough market realities to prevent a decline in artistic quality.

\footnotetext{
* This study was implemented in the framework of the Programme of Fundamental Studies 2013, National Research University Higher School of Economics, Moscow.

Corresponding author: Tatiana Abankina, Ph.D. in economics, professor, director, Center of Public Economy Sector, National Research University Higher School of Economics, Moscow, Russia; research fields: economics of arts and culture, arts and culture funding, culture policy, organizational and economic mechanisms, and legal issues of arts and culture development.
} 
However, at the end of the 20th century, budget funds and sponsorship of cultural institutions have been decreasing every year. Moreover, all financial donors, including state and municipal authorities, charitable foundations, private sponsors and patrons, began to support cultural organizations depending on their performance and social impact of their activities. It was a powerful impetus for the revision of the culture's place and role in society, of the management technologies applied by cultural organizations and their capacity to work with different audiences and to attract public attention. Since the 70s, cultural workers in the European countries initiated a wide debate on the issues of culture-Why it is important for society as a whole and for specific local communities, how it could contribute to new economy and social development, and what share it has in the post-industrial urban and regional development.

The search for new solutions to provide resources and support for culture goes in the direction of enhancing culture, state, and business interactions on the principles of social partnerships. The consequences of the financial crisis have shown that only a combination of budgetary and extra-budgetary long-term funding would provide for artistic independence and economic autonomy of cultural institutions. With the accelerating pace of social change, the role of culture increases - Culture moves from the periphery to the center of social interests and public attention. Sometimes, it is argued that a rapid development of so called creative industries in Europe is a response to the economic crisis in traditional industries such as steel and textile. It is not quite so. The economy of most European countries that started to actively develop creative industries was on the rise. Actually, it allows them to accumulate a certain "safety margin" and to make a transition to post-industrial type of economic development, to withdraw outdated industries from the cities, to improve urban environment through the revitalization of the vacant industrial areas and construction of new cultural facilities, and in fact to create new cultural infrastructure. The development of creative (cultural industries) was more likely program of social adaptation that advanced the transition to "new employment" in post-industrial economy.

Not all European countries followed the path of de-industrialization, many began to develop cultural industries in addition to the existing industries while actively modernizing them and introducing new technologies. Nevertheless, all countries demonstrate a significant change in their attitudes toward cultural sector, a tendency to turn it into a profitable sector of modern economy, to study, realize, evaluate, and use the economic potential of the accumulated and newly created wealth, and to actively incorporate it in the economic activities, in modern lifestyle.

The state and a thin layer of aristocratic families can no longer shoulder the burden of preserving, and what is more, of developing the arts and culture. State budgetary support and elite patronage technologies are gradually replaced by the democratic technologies of social partnership. Each country develops its own funding model for arts and culture. At the same time, all counties are in continuous search of an integral concept substantiating a combination of different instruments of financial support for cultural sector, their efficiency and sustainability. For all the diversity of cultural sub-sectors and the difference of their economic situation, arts and culture are seen as one important sector of national economy and society, and its development requires the state to work out an extensive support system.

\section{Paternalistic Model for Culture Support}

The basic concept, underpinning the state support for arts and culture is certainly the theory of patronized goods and its further developments. Many experts rightly view culture as mixed goods, but the key value here is their merit nature or the social importance and public interest in stimulating their consumption. A. Rubinstein 
following the Musgrave's tradition of public finances has developed the theory of markets of patronized goods, i.e. those patronized by the state (Rubinstein, 2009a). Within the framework of "economic sociodynamics" theory, one of the key theses to justify the state support for culture is the need to compensate for cost disease in arts and culture, a phenomenon studied in the works of W. Baumol and W. Bowen boils down to the fact that the production costs in the performing arts always grow faster than revenue (Baumol \& Bowen, 1966). This phenomenon was examined and confirmed in the course of the empirical study of all Russian theatres, concert organizations, and museums for the period of 1990-2010 (Rubinstein, 2012).

Thus, the first model of the state support for culture stemming from the theory of the merit goods can be called a "paternalistic" model. The essence of the paternalistic model of the state support for culture is to offset the cultural organizations' revenue shortfall by the budgetary subsidies. Within the paternalistic model, arts and culture are funded through budgetary allocations. In most of the developed European countries, budgetary funding remains one of the main forms of arts and culture support. However, the share allocated for these needs in the total expenses of the state budgets is comparatively small-from $0.2 \%$ to $2.5 \%$. In Russia, the proportion of expenditure on culture in the consolidated budget accounted for about $2.0-2.5 \%$ during the last decade, and in recent years, it has been slightly decreasing (Abankina, Kushtanina, Romanova, \& Rudnik, 2014). To compare the budgetary expenditure on culture in Russia with that in OECD (Organization for Economic Cooperation and Development) countries, the author uses the expenditures on culture as a percentage of GDP (Gross Domestic Product) (see Table 1). The analysis shows that by the share of expenditure on culture in GDP, Russia lags behind the developed countries and the OECD average.

Each country with the selected financial methods, forms, and mechanisms develops its own model for arts and culture budgetary funding which is heavily influenced by such factors as the established attitudes of the state toward arts and culture, and the specifics in the public policy in the sector. Paternalistic model of arts and culture funding is determined by the degree of centralization or decentralization in public administration, and the fiscal relations between different levels of government. In unitary states, such as Sweden, the central budget continues to play the key role, while in the federal state of Germany, its economic functions are reduced to funding of broadcasting and international cultural activities.

The state budgetary support for arts and culture is provided through several channels:

(1) Direct financing;

(2) General and targeted transfers to subnational budgets;

(3) Pooled funding from the governments of different levels.

The direct financing is used in all the countries, but its biggest share is the budgets of the European unitary states. It is carried out in the form of full funding of operating costs and capital investments, special targeted transfers, and in the form of grant as well. The oldest method of the state support for culture-full direct financing — has already been rejected by most countries. This way of subsidizing is still used for some national museums, archives, libraries, or to support national broadcasting companies. Special purpose transfers are commonly used for the implementation of national culture development programs. The most common form of the direct state financing is a grant support; grants are given to both organizations and individuals in cultural sector; the terms and conditions of their provision vary significantly from country to country.

In addition to the direct budgetary allocations, arts and culture can be supported indirectly through tax incentives. It is justified by special public importance of creative labour and its products. Tax-benefit system usually applies to both producers of cultural goods and services and donors, patrons in cultural sector. 
Table 1

Expenditure on Culture in Russia and OECD Countries (as a Percentage of GDP)

\begin{tabular}{|c|c|c|c|c|c|}
\hline Country $^{*}$ & 2005 & 2008 & 2010 & 2011 & 2012 \\
\hline Iceland & 1.24 & 1.36 & 1.25 & 1.16 & 1.16 \\
\hline Luxemburg & 1.65 & 1.21 & 1.16 & 1.14 & 1.13 \\
\hline Estonia & 1.48 & 1.56 & 1.34 & 1.25 & 1.11 \\
\hline Slovenia & 0.92 & 0.93 & 1.04 & 1.00 & 0.98 \\
\hline The Netherlands & 0.89 & 0.82 & 0.90 & 0.85 & 0.86 \\
\hline France & 0.71 & 0.79 & 0.77 & 0.78 & 0.79 \\
\hline Denmark & 0.71 & 0.67 & 0.72 & 0.71 & 0.74 \\
\hline Czech Republic & 0.70 & 0.71 & 0.83 & 0.78 & 0.72 \\
\hline Malta & 0.41 & 0.47 & 0.59 & 0.64 & 0.70 \\
\hline Poland & 0.72 & 0.88 & 0.72 & 0.68 & 0.67 \\
\hline Hungary & 0.79 & 0.78 & 0.82 & 0.77 & 0.65 \\
\hline Austria & 0.60 & 0.62 & 0.64 & 0.62 & 0.62 \\
\hline The OECD average & 0.65 & 0.66 & 0.66 & 0.63 & 0.62 \\
\hline Norway & 0.54 & 0.55 & 0.64 & 0.62 & 0.60 \\
\hline Lithuania & 0.69 & 0.80 & 0.69 & 0.62 & 0.59 \\
\hline Spain & 0.61 & 0.74 & 0.69 & 0.61 & $\mathrm{n} / \mathrm{a}$ \\
\hline Sweden & 0.59 & 0.62 & 0.61 & 0.59 & 0.57 \\
\hline Finland & 0.49 & 0.50 & 0.57 & 0.57 & 0.57 \\
\hline Russian Federation & 0.55 & 0.60 & 0.60 & 0.55 & 0.55 \\
\hline Germany & 0.46 & 0.43 & 0.44 & 0.45 & 0.44 \\
\hline Bulgaria & 0.39 & 0.44 & 0.38 & 0.41 & 0.43 \\
\hline Portugal & 0.53 & 0.44 & 0.47 & 0.43 & 0.42 \\
\hline Ireland & 0.35 & 0.45 & 0.39 & 0.40 & 0.39 \\
\hline Italy & 0.42 & 0.41 & 0.39 & 0.36 & 0.34 \\
\hline Cyprus & 0.35 & 0.36 & 0.40 & 0.42 & 0.34 \\
\hline Great Britain & 0.41 & 0.39 & 0.37 & 0.34 & 0.33 \\
\hline Greece & 0.15 & 0.24 & 0.23 & 0.26 & 0.26 \\
\hline
\end{tabular}

Note. * Countries are given in descending order of expenditures on culture (as a percentage of GDP) according to the 2012 data. Sources: Eurostat data base (for OECD countries) and calculations of the Institute of Public Resource Management, Higher School of Economics (for the Russian Federation).

\section{Investment Model for Culture Support}

A new perspective of arts and culture support models is connected with the dissemination of human capital theory, which is developed almost in parallel with the theory of public goods (Becker, 1964; Musgrave, 1996; Shultz, 1968). The key point that differentiates the new view from the approach based on the theory of merit goods is that the human capital theory gradually but radically changes the attitude toward the state support for education, health care, culture, and ecology — They are considered to be not so much important social needs to be "patronized" by the state as the investments that can bring returns (Mincer, 1994).

Initially, human capital referred to a sum of investments increasing human ability to perform labour - education and professional skills. Then, the concept of human capital has been significantly expanded. Recent calculations made by the World Bank experts include household expenditures as well-food, housing, education, health care, culture, and the government spending for these purposes. Further fundamental and applied studies of the human capital value, its contribution to socio-economic development of the cities and 
nations, evaluation of return on human capital investment, gradually made these notions to be included in political agendas and strategy documents in different countries, including Russia. Thus, the "Concept of Long-term Socio-economic Development of the Russian Federation for the Period up to 2020" regards culture as having "a leading role in the formation of human capital, creating knowledge-based economy". The reason for the exceptional role of culture in the transition from resource-based economy to innovation economy lies in higher professional requirements, "including the level of intellectual and cultural development that is possible only in a cultural environment enabling realization of the objectives and ethical values of the society's development".

Thus, the second model of the state support for culture derived from the human capital theory might be called an "investment" model. The investment model implies that increasing public investment in humanitarian sphere contributes to the transition to innovation, knowledge-based economy, and sustainable socio-economic development.

Financial support for cultural sector within the investment model exceeds the budgetary allocations for arts and culture, the funds as well come from broader socio-economic programs supporting regional development, job creation, small and medium enterprises, reconstruction of urban economic infrastructure, and vocational training and development. The value of co-funding for the cultural organizations and investment projects from budgetary and extra-budgetary sources increases. In Europe, partnerships and cooperation of the government and corporate sponsors in cultural sector financing become more evident form of support which contributes to a considerable inflow of funds from private sector. The investment model also implies the functions of financing culture dispersed among different authorities and agencies. For example, Ministry of Defense funds military bands, Ministry of Justice — cultural activities in penal institutions, Ministry of Education — teaching different disciplines related to culture in secondary schools. Interdepartmental cultural investment programs are developed in order to make budgetary funding more efficient.

Many countries along with the budgetary funds more often use public financing from extra-budgetary funds; their formation is grounded by "special financial needs" of cultural sector or "national interests" in human capital development. The resources are pooled from the central budget revenues as well as the taxes on radio and TV companies, film service, and other special taxes. There are significantly expanded tax and other incentives for private donors. These measures help attract substantial investments to renovate and upgrade theatres and art galleries. In addition to the taxes, generally used for the cultural sector, there are specific forms of taxation, connected with the specificity of income generation in the sector, introduced to accumulate investment resources. Some Nordic countries and France have a specific tax such as one percent of public construction costs used for the acquisition of art works.

Many countries widely use intermediary NGOs (Non-Governmental Organizations) to allocate the resources for human capital development. The arm's length principle prevails as it minimizes government officials' participation in the assessment of the works of art, creative activities of cultural organizations and professionals. It is one of the most democratic methods providing high efficiency of public investments in cultural sector on a competitive basis.

\section{Stimulating Model for Culture Support}

A modern approach to the financing of culture is associated with the transition to a post-industrial type of socio-economic development. Some European countries, notably the Netherlands and the United Kingdom, 
choose de-industrialization as the leading development strategy for their cities. Since the 70 s of the last century, support for culture has become a strategic priority in these countries. Then developed projects formed the basis for the programs to support creative sector-Creative industries that help increase the investment attractiveness of the territories contribute to workforce development, stimulate innovations and creativity, and enhance the competitiveness of the cities and countries. Creative industries development has become a social adaptation program that enabled many countries to move to the "new employment" in the post-industrial development.

Since that time, we see the rise of creative economy; its theoretical propositions are developed in the works, already classic ones, by John Howkins, Richard Florida, Charles Landry, and many other researchers and experts (Florida, 2005; Howkins, 2007; Landry, 2000). As a result, they have formed a three-dimensional picture of a creative cluster in today's world - the planet with its creative ethnos, new economy, and developing cities. With these current trends, culture is regarded as a resource for new economy, development actor, and a source for new thinking. Widely discussed and substantiated is the thesis that culture accumulates positive effects in various areas, makes it possible to turn weaknesses into strengths; that the enhanced cooperation of cultural organizations and other institutions stimulates improvements in urban environment, tourism development, and growth of investments, thereby initiates job creation and helps to find solutions of current social and economic problems.

Thus, the third model of state support for culture, arising from the creative economy concept, can be described as "stimulating" model. The stimulating model of state support for culture envisages development of enabling environment for creative industries and an influx of creative individuals due to high migration attractiveness of the country to ensure its international competitiveness and advanced social and economic development in the global economy.

Practically, culture financial support in the creative economy focuses on three main areas:

(1) Creation of a favorable environment for creative businesses;

(2) Tax incentives and preferences for creative individuals and organizations;

(3) Protection of intellectual property and copyright.

One of the main financing mechanisms here is program and project finance. The creative industries have long since become an established priority in the development strategies, cultural and social agendas of many cities in Europe, Asia, and America. The cities overstepping the limits of their countries become global or world cities, they find their own identity and the place on the world map. De-industrialization projects with the support for creative clusters have been implemented in the US, Canada, Germany, France, Austria, Spain, and Great Britain (Creative London strategy was one of the first papers of the kind). Large-scale programs supporting creative industries are launched in the countries of Southeast Asia and primarily in China. In Russia, creative clusters appeared quite recently. And it has just started developing sustainable mechanisms to support creative industries in the regions and cities (Abankina, 2013).

The stimulating model of arts and culture support in European countries is implemented through the adoption of public support measures to improve financial conditions for artists and other creative professionals. They usually have additional privileges on the deduction of the costs for their professional activities from the tax base. With the development of commercial activities of cultural organizations, a bank loan plays increasingly important role in their funding system. State assists cultural organizations in obtaining bank loans by providing loan guarantees. The main thing is that the venture capital companies start to actively work with cultural projects and creative entrepreneurship. The stimulating model of arts and culture support widely uses 
matching grants. The objective of these grants is not only to improve the financial situation of cultural institutions but also to promote their adaptation to the market environment.

Intellectual property protection is one of the key areas in supporting creative industries. Uncontrolled mass reproduction and replication of the creative products generates a problem of compensation for the income loss of the authors, performers, and producers. The problem was largely solved by the expansion of copyright and related rights and introduction of special duties on copying, technical means in order to use it someway or other for reimbursement of these losses.

\section{Conclusions}

In conclusion, it can be stated that the identified models - paternalistic, investment, and stimulating — are not necessarily alternative; they complement each other rather than exclude. This reflects cultural sector phenomenon, as it is a syncretic, compound, and human-centered sector of the modern economy. Only by combining financial instruments aimed at different outcomes is it possible to pool necessary resources from different sources to ensure rigorous development of cultural sector. It is the convergence of financial instruments that makes it possible to create an ecosystem of culture, providing its diversity.

Providing cultural diversity is essential to respond to the challenges of modern audiences of "new type"-Their interests are focused on border crossings. This is so-called "the new culture consumer". They choose and prefer at the same time ethnic (local) and world, popular and high, traditional and contemporary culture. One night they listen to the opera, and the next they go to a rock concert or a laser light show. During the holidays, they visit traditional museums and pop concerts, contemporary arts exhibitions and local folk festivals. The boundary between "elite" and "mass" culture is blurring. Modern cultural resource is very dynamic, what was radical just yesterday, becomes classics today. In such circumstances, only the support for arts and culture and cultural heritage through a wide range of financial instruments can provide matching supply with demand in the field of culture, which can be characterized as a space of "symbols". Production and consumption of symbols satisfies high, non-material needs, according to the Maslow's famous hierarchy of needs. Working on the market of symbols is working not with the goods and services but with social and psychological motives, desires, values, and prejudices of people in situations where consumption of material things reflects the intangible social needs. Thus, culture turns into a strategic resource that allows us to receive economic benefits from non-economic goods-symbolic attributes and privileges, tangible and intangible elements of reputation, legends and myths, cultural traditions, dreams and prejudices, tastes and likings of the audiences.

\section{References}

Abankina, T. (2013). Regional development models using cultural heritage resources. International Journal of Culture, Tourism and Hospitality Research, 7(1), 3-10.

Abankina, T., Kushtanina, E., Romanova, V., \& Rudnik, B. (2014). State support for culture. Moscow: Higher School of Economics.

Baumol, W. J., \& Bowen, W. G. (1966). Performing arts: The economic dilemma. New York, NY: The Twentieth Century Fund. Becker, G. S. (1964). Human capital. New York, NY: Columbia University Press.

Florida, R. (2005). The rise of the creative class: And how it's transforming work, leisure, community and everyday life. Moscow: Klassika-XXI.

Howkins, J. (2007). The creative economy: How people make money from ideas. London: Penguin Books. Landry, C. (2000). The creative city: A toolkit for urban innovators. London: Earthscan Publications, Ltd. 
Mincer, J. (1994). The production of human capital and the lifecycle of earnings: Variations on a theme. Working Paper of the NBER, No 4838. Retrieved from http://www.nber.org/papers/w4838.pdf

Musgrave, R. A. (1996). Public finance and finanzwissenschaft traditions compared. FinanzArchiv, 53(2), 145-193.

Rubinstein, A. (2009a). On the theory of patronized goods. Article 1. Patronized goods and their place in the economic theory. Obshchestvennye Nauki i Sovremennost (Social Sciences and Modernity), 1, 139-153.

Rubinstein, A. (2009b). On the theory of patronized goods. Article 2. The sociodynamic description of the markets of patronized goods. Obshchestvennye Nauki i Sovremennost (Social Sciences and Modernity), 2, 138-150.

Rubinstein, A. (2012). Patronized goods in cultural sector: Signs and consequences of the cost disease. Moscow: Institute of Economics of Russian Academy of Sciences.

Shultz, T. (1968). Human capital. In D. L. Sills (Ed.), International encyclopedia of the social science (vol. 6) (pp. 12-34). New York, NY: Macmillan.

United Nations. (n.d.). Creative economy report 2010. Retrieved from http://unctad.org/es/Docs/ditctab20103_en.pdf 